Neth. J. PI. Path. $96(1990) 35-46$

\title{
Effects of powdery mildew and weather on winter wheat yield. 2. Effects of mildew epidemics
}

\author{
R.A. DAAMEN' and I.T.M. JORRITSMA ${ }^{2 *}$
}

1 Research Institute for Plant Protection (IPO), P.O. Box 9060, 6700 GW Wageningen, the Netherlands

2 Department of Theoretical Production Ecology (TPE), Agricultural University, P.O. Box 430, 6700 AK Wageningen, the Netherlands

Accepted 9 October 1989

\begin{abstract}
Wheat yicld losses caused by powdery mildew were computed based on effects of the disease on leaf photosynthesis. Powdery mildew was introduced in a crop model of wheat by quantification of five parameters, taking the vertical and horizontal distribution of mildew in the crop into account. The most important parameters were those of the mildew intensity, the distribution of mildew in the crop, and the effect of mildew on assimilation at light saturation. Measured mildew cpidemics in ficld experiments in three different years, were used to compute yield losses. Computed losses were compared to measured losses. On average, computed yield loss approached measured, but measured yicld loss was underestimated, especially in early mildew epidemics due to the computation of partitioning and reallocation of assimilates. Other processes which may cause an underestimation are described. The use of crop models as a method to upgrade disease management systems is discussed.
\end{abstract}

Additional keywords: Triticum aestivum, Erysiphe graminis DC. ex Merat, Blumeria graminis (DC.) Speer, simulation, SUCROS87, sensitivity analysis.

\section{Introduction}

A vital question to upgrade disease management systems is whether damage functions, established in years with specific weather conditions, can be applied also in years with other weather conditions and crop husbandry practices. Though repeated measurements in many years and locations may answer this question, they will not lead to general methods to enable these extrapolations to be made. Models of crop growth, which compute yield from temperature and radiation, provide another option to answer the question if they can be combined with models of the pathogen. Rabbinge et al. (1985) quantified the effect of powdery mildew on photosynthesis of wheat leaves (Allen, 1942; Walters and Ayres, 1984). How these effects on photosynthesis measured in the laboratory may be used to estimate loss of kernel yield and to what extend they explain yield loss caused by mildew in the field remained to be answered.

* Present address: Dorschkamp Research Institute for Forestry and Urban Ecology, P.O. Box 23, 6700 AA Wageningen, the Netherlands 
In a previous paper, the performance of three wheat models was compared to yields harvested in the Netherlands. It was indicated that the effect of weather in different years on yield could not yet be calculated accurately. Therefore, the main objective, the effect of weather on the damage function by mildew, could not be assessed in this study. Our objective for this paper was to introduce mildew in a wheat model, and to assess how this affects computed damage compared to measured damage in the field. By this comparison, crucial processes of the model determining damage are identified. In this paper, loss of kernel yield by mildew is called damage.

\section{Materials and methods}

Crop model. The general structure of the SUCROS87 model (Spitters et al., 1989) was chosen as a framework to quantify the effect of mildew. Computations were made with SUCROS87E (Daamen and Jorritsma, 1990), an adapted version of the SUCROS87 winter wheat model (Spitters et al., 1989). Simulation begins at sowing time.

Field experiments. Simulated damage was compared with damage measured in three field experiments. They were near Wageningen, on the farms 'De Schuilenburg' in 1979-1980 and 'De Bouwing' in 1980-1981 and 1982-1983, and suffered light to moderate mildew epidemics (Fig. 1). A detailed description of these experiments was given by Daamen $(1988,1989)$.
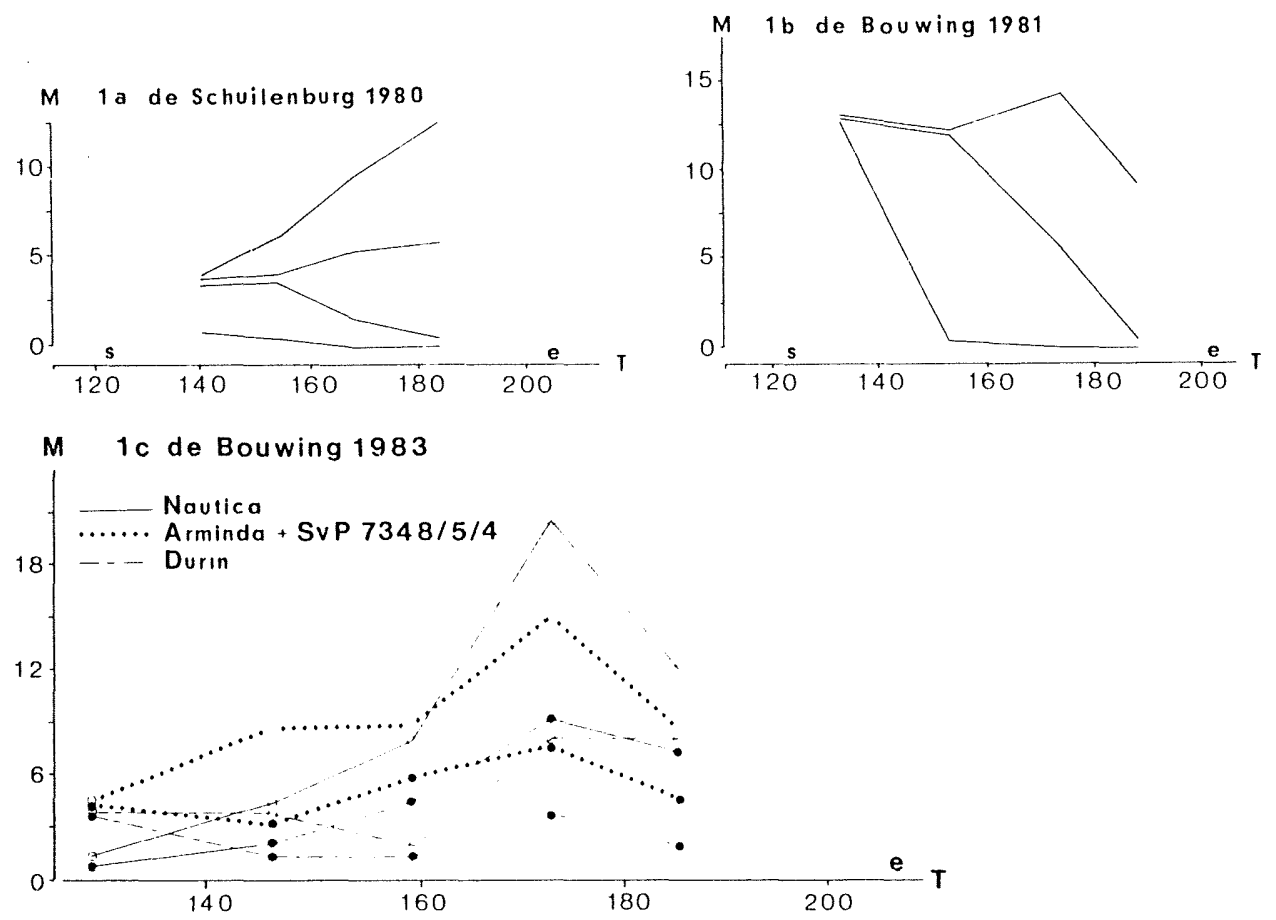

Fig. 1a, b, c. Courses of the nildew epidemics in the experiments ( $M$ is average number of mildew pustules per leaf, Day is days since 1 January), used as input in the simulation models. $s$ is start of the epidemic, $\mathrm{e}$ is end of the epidemic and of kernel filling. 

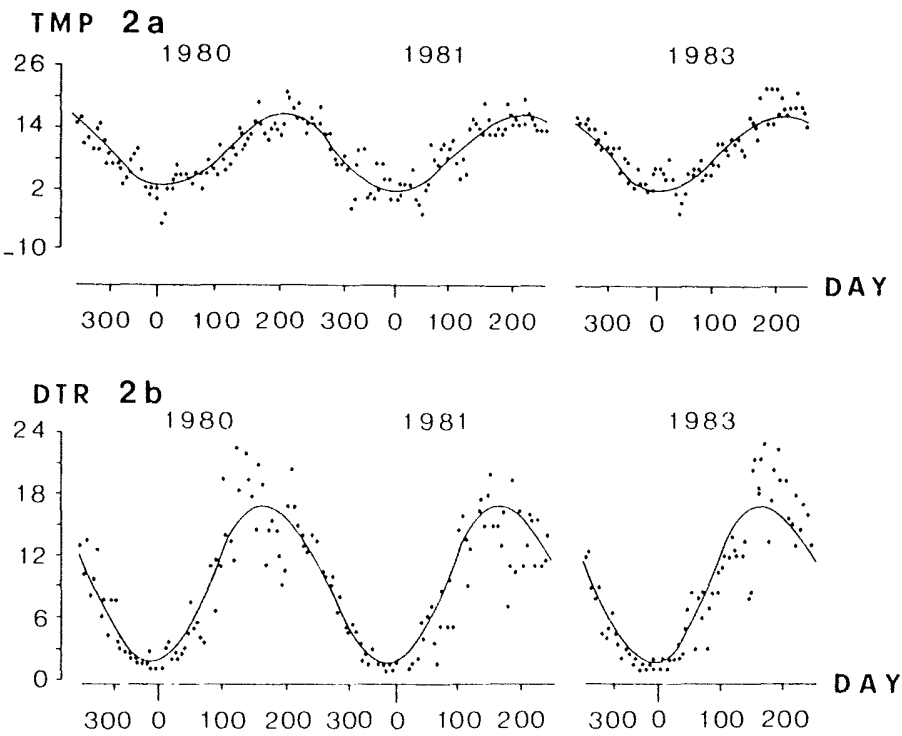

Fig. 2a, b. Average daily temperature (TMP, ${ }^{\circ} \mathrm{C}$, average of five-days) and average daily total global radiation (DTR, $M J \mathrm{~m}^{2}$ day ', average of five days) in Wageningen in the different cropping seasons. The curves are averages for Wageningen in 1950-1980.

During the three cropping seasons, weather differed considerably (Fig. 2a, b, meteorological station Wageningen). In 1980, radiation was high during May and early June, but low in late June and early July, when temperature was below average. In 1982-1983, autumn and winter were relatively warm. Radiation was low during May and June, but high in July. The season 1980-1981 did not deviate much from average, though early spring was relatively warm with low radiation and summer had lower radiation than average.

Simulation of the experiments. The dates of sowing and end of kernel filling (DC83, Zadoks et al., 1974) were used to start and stop the simulations. Daily radiation and temperature (Fig. 2a, b) determined crop growth, and the measured mildew epidemics (Fig. 1) determined the damage. Mildew intensity was measured by Rabbinge et al. (1985) as the $\%$ leaf area diseased on single leaves both-sided $\left(P_{\mathrm{i}}\right)$, whereas in the field, average pustule number $(M)$ at the upperside per leaf layer was determined. In the severity assessments made by Rabbinge et al. (1985), pustule size was about $0.04 \mathrm{~cm}^{2}$ (Schans, 1983) which, at an average leaf size of $20 \mathrm{~cm}^{2}$ (Daamen, 1989), corresponds with a rating of $0.2 M \%$ severity, uppersided, in the field (Ubels and Van der Vliet, 1979). Average mildew intensity, both-sided per leaf layer may be estimated at 1.5 times the upperside intensity (Daamen, 1986). Mean pustule number per leaf layer $(M)$ in the field, is transformed to mean mildew severity both-sided per leaf layer $(P)$ by $(0.2 \times$ $1.5)$ :

$$
P=a \cdot M \quad ; \quad a=0.3
$$


Mildew profile. The number of leaves per culm, and the average mildew severity in each layer at each observation date describe the vertical distribution of mildew in the field and were used to simulate damage. Between observation dates, a linear interpolation of the disease intensity in each layer was made. Mildew on ears was negligible in the experiments.

To identify main parameters, artificial instead of measured mildew epidemics were used. The mildew profile was then estimated from the average mildew severity over all leaf layers $(\bar{P})$ or (Daamen, 1989):

$$
P_{\mathrm{d}}=\widetilde{P} \cdot b \cdot\left(L_{\mathrm{d}} / L_{\mathrm{t}}\right)^{\mathrm{b}-1} \quad ; \quad b=3.4
$$

in which $P_{\mathrm{d}}$ is the mildew severity at depth $d$ in the canopy of leaves and $L_{\mathrm{d}} / L_{\mathrm{t}}$ is the leaf area above depth $d$ relative to total leaf area, which is computed by the model.

Effect of mildew on assimilation at light saturation. The effect of mildew severity $\mathrm{Pi}$ on the assimilation rate at light saturation $\left(A_{\mathrm{m}}, \mathrm{kg} \mathrm{CO}_{2}\right.$ ha ' leaf $\left.\mathrm{h}{ }^{\prime}\right)$ of single full-grown top leaves in relation to the development of the culm was studied by Schans (1983), Van Vrede (1983) and Jorritsma (1986). The relation is described by a hyperbolic equation with an additive effect of the developmental stage (equation 3 in: Rabbinge et al., 1985). In the crop model, the maximum photosynthetic capacity of healthy leaves in the canopy $\left(A_{\mathrm{nm}}\right)$ depends on the developmental stage and the temperature (Spitters et al., 1989). The hyperbolic equation with an additive effect of developmental stage (Rabbinge et al.,1985) was rewritten as a multiplicative one, by standardization at the average $A_{\mathrm{m}}$ of the measurements without disease stress (43.4; Jorritsma, 1986) at $20^{\circ} \mathrm{C}$ :

$$
A_{\mathrm{m}}=A_{\mathrm{pm}} \cdot\left(1-\left(28-\frac{87}{3.1+P_{\mathrm{i}}}\right) / 43.4\right)
$$

Effect of the horizontal distribution of mildew. As the effect of mildew on $A_{m}$ is curvilinear (3), computations with the average of $P_{i}$ per leaf layer will overestimate the effect on $A_{\mathrm{m}}$. Though the exact distribution of pustules on full-grown leaves is not known, the negative binomial (Waggoner and Rich, 1981) was used to remove this bias. The dependence of the cluster parameter of this distribution on the mean pustule number $(M)$ was estimated (Taylor et al., 1979) from a descriptive relation (equation 6 in: Daamen, 1986). Probability density functions of mildew at mean densities of $M=1$ to $M=29$ were generated by the negative binomial distribution, using the estimates of the cluster parameter, and (1) and (3) were used to estimate the effect of the average mildew severity $P$ per leaf layer on $A_{\mathrm{m}}$. The result was described by a negative exponential relation (Fig. 3 ):

$$
A_{\mathrm{m}}=A_{\mathrm{pm}} \cdot\left(1-c \cdot\left(1-\mathrm{e}^{d \cdot P}\right)\right) \quad ; \quad P<10 \%
$$

The dimensionless parameters: $c=0.46(\mathrm{SE}=0.01)$ and $d=-0.29(\mathrm{SE}=0.01)$ described the computed data adequately at mildew severities below 10\%; the SE of residuals was 0.007 . Equation 4 was used in the model. 


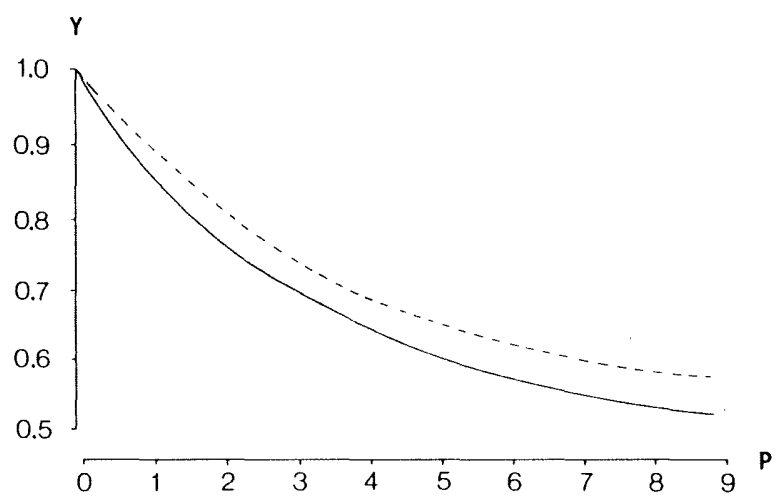

Fig. 3. Maximal photosynthetic capacity of wheat leaves at light saturation (Y, in relative units) in relation to the percentage mildew coverage $(P)$. The solid line is the relation for individual leaves $\left(P_{\mathrm{i}}\right.$, equation 4$)$, the broken line is the relation for the average mildew intensity in a leaf layer, taking the distribution of mildew into account ( $P$, equation 5 ).

Other effects of mildew. The light use efficiency $(E)$ tended to decrease with mildew intensity but was not significantly lower than that of healthy leaves $\left(E_{\mathrm{p}}\right)$ (Rabbinge et al., 1985). The model assumes no photosynthesis in the diseased leaf area, conform Waggoner and Berger (1987):

$$
E=E_{\mathrm{p}} \cdot(1-f . P / 100) \quad ; \quad f=1
$$

in which parameter $f$ is made explicit to facilitate the evaluation of this assumption. For other effects of mildew, such as on reflection and transmission of radiation and on maintenance and dark respirations, diseased leaf area was assumed to behave like healthy leaf area.

\section{Results}

Computed yields at the different mildew epidemics approached harvested (Table 1). Without mildew, computed yields were higher than harvested in 1980 and 1981 and nearly equal to harvested in 1983 (Table 1, disease free). Crop husbandry in 1980 was less intensive than in the other years. In 1981 lodging occurred in the experiment. Accordingly, end of kernel filling in the experiments in 1980 and 1981 took about two weeks earlier place than simulated, whereas such a difference was absent in 1983.

Damage by mildew was underestimated in the simulations for 1980 and $1981(p<$ 0.05 ), and almost exactly estimated for 1983. Underestimation of damage remained if simulations for 1980 and 1981 were not stopped by the observed dates of end of kernel filling.

Interpretation of simulated damage. From the experiments it is unclear whether differences in computed damage are due to different types of epidemics or to weather in the different years. Therefore, damage by artificial epidemics with a mildew stress of 240 pustule-days per leaf was computed at different periods in the three harvest years.

Neth. J. Pl. Path. 96 (1990) 
Table 1. Measured and computed yields in percentages (in kg dry weight are, between brackets) in relation to the mildew stress, expressed in the number of pustule-days per leaf.

\begin{tabular}{llll}
\hline Experiment & $\begin{array}{l}\text { Mildew } \\
\text { stress }\end{array}$ & $\begin{array}{l}\text { Measured } \\
\text { yield }\end{array}$ & $\begin{array}{l}\text { Computed } \\
\text { yield }\end{array}$
\end{tabular}

De Schuilenburg $1980^{1}$

cv. Caribo

disease free

0

nearly disease free

early epidemic

132

suppressed epidemic

304

full epidemic

551

100
99
98
95
89

(63.3)

100

(70.4)

De Bouwing $1981^{2}$

cv Okapi

disease free

very early epidemic

early epidemic

0
194
569

full epidemic

569
850

\begin{tabular}{|c|c|}
\hline $100 \quad(66.0)$ & 100 \\
\hline 97 & 100 \\
\hline 94 & 98 \\
\hline 89 & 95 \\
\hline
\end{tabular}

$(70.9)$

98

100

96

93

De Bouwing $1983^{3}$

cv. Nautica

disease free

suppressed epidemic

full epidemic

0
332
649

100

(79.1)

$100 \quad(78.7)$

cv. Arminda

disease free

suppressed epidemic

332
649

94

88

full epidemic

$\begin{array}{rr}0 & 100 \\ 378 & 95\end{array}$

(77.1)

100

95

588

92

93

line SVP 7348-5-4

disease free

$0 \quad 100$

358

100
95

(77.3)

100

(78.7)

full epidemic

711

91

95

cv. Durin

disease free

suppressed epidemic

0

180

100

full epidemic

395

(81.0)

100

(78.7)

$\overline{1,2,3}$ year of harvest, measured relations are $0.012,0.009$ and $0.010 \mathrm{~kg}$ dry weight are ${ }^{-1}$ damage per pustule-day of mildew per leaf, respectively. SED of measured yield is c. $2.2,1.4$ and $1.0 \%$, respectively.

In addition to damage, computed losses of total shoot weight are also given in Table 2. Mildew stress during vegetative growth affected kernel yield hardly, while damage due to mildew stress during kernel filling was high. Such a systematic effect was not observed in the loss of total shoot weight (Table 2). Simulated loss of total shoot weight was 40

Neth. J. Pl. Path. 96 (1990) 
Table 2. Computed losses due to early, middle and late artificial epidemics, each with a mildew stress of 240 pustule-days per leaf. Loss of kernel yield (damage) is given as percentage of those of clean crops. Loss of total shoot weight is given between brackets.

\begin{tabular}{|c|c|c|c|c|}
\hline Epidemic & 1980 & 1981 & 1983 & \\
\hline Early, day $120-155$ & $(2.1)$ & $(1.5)$ & 0.5 & (1.4) \\
\hline Middle, day $145-180$ & $(1.0)$ & $(1.3)$ & 2.0 & (1.8) \\
\hline Late, day $170-205$ & $(1.3)$ & (1.7) & 6.1 & $(2.7)$ \\
\hline
\end{tabular}

high during stress periods with high radiation, as in Spring 1980 and Summer 1983. Thus, simulated shoot weight depends mainly on the total amount of assimilates available, whereas simulated damage (loss of kernel weight) depends mainly on the assimilation during kernel filling. This difference is due to the computation of partitioning and reallocation of assimilates. These simulations show that the later the mildew stress, and the higher the radiation during kernel filling, the higher the computed damage.

In 1983, radiation was higher than average during kernel filling, and the epidemics were late, especially those in cvs. Nautica and Durin (Fig. 1 and 2). Radiation was slightly below average during kernel filling in 1980 and 1981. The mildew epidemic of 1980 was late and the 1981 one early. Thus, differences between years in simulated damage (Table 1) were mainly due to the different weather conditions and partly due to differences in courses of the epidemics.

The timing of the mildew stress within and between years has a clear effect on computed damage. In the field experiments, measured damage function did not depend significantly on year or on the developmental stage (Table 1 and Daamen, 1989).

Sensitivity analyses. To evaluate the importance of the parameters that quantify the effect of mildew in the model, kernel yields were computed at different parameter values for the growing seasons 1975-76 to 1985-86. Yields were computed at an artificial mildew epidemic, starting at day 120 , increasing linearly up to day 180 and decreasing linearly to day 220 , with a stress of 1000 pustule-days per leaf. This is a severe disease stress for the Netherlands. The response of the model to a change in value of parameter ' $x$ ', being $a, b, c, d, f$ and the maintenance and dark respiration, respectively, was described. No estimates were available of their variances in the field. Therefore, each parameter was set arbitrarily to a lower and an higher value, respectively, keeping the other parameter values at their estimated value. The responses of the model to changes in the values of the parameters was described by:

$$
\text { Yield }_{\mathrm{i}}=u_{\mathrm{i}}+v \cdot x+w_{\mathrm{i}} \cdot x+\text { error } \quad ; \quad \mathrm{i}=\text { harvest year }
$$

To identify main parameters, a standardized regression coefficient $\left(v_{\mathrm{m}}\right)$ was computed by multiplication of $v$ from (6) with average $(x)$ /average(Yield). This $v_{\mathrm{m}}$ is the percentage response in computed yield due to a percentage change in the value of parameter ' $x$ '. It can be used to compare the effect that the different parameters have on the model if the average yield of the runs for each parameter are equal and if the average value of the parameters have a meaning. Here, the average yield of $83 \mathrm{~kg}$ dry weight $\operatorname{are}^{-1}$

Neth. J. Pl. Path. 96 (1990) 
Table 3. Response of computed yields, with artificial epidemics of 1000 pustule-days of mildew per leaf, to changes in parameter values ( $x_{h}$ and $x_{1}$ are higher and lower values, respectively) which quantify the effect of mildew, see text. Given are average values over the cropping seasons $1975 / 76$ to $1985 / 86$, by analysis of covariance (Eqn 6). $R^{2}$-values were calculated after elimination of the effect of year. $R^{2}$ error indicates deviations from linearity.

\begin{tabular}{|c|c|c|c|c|c|c|c|c|}
\hline Eqn & Parameter & $\bar{x}$ & $x_{11}$ & $x_{1}$ & $v_{m}^{*}{ }^{*}$ & $R^{2} v x$ & $R^{2} w_{1}, x$ & $R^{2}$ error \\
\hline 1 & $a$ & 0.3 & 0.4 & 0.2 & -0.06 & 0.989 & 0.008 & 0.003 \\
\hline 2 & $b$ & 3.4 & 4.4 & 2.4 & 0.07 & 0.958 & 0.015 & 0.026 \\
\hline 4 & $c$ & 0.46 & 0.56 & 0.36 & -0.07 & 0.971 & 0.028 & 0.001 \\
\hline 4 & $d$ & 0.29 & 0.35 & 0.23 & -0.04 & 0.986 & 0.012 & 0.002 \\
\hline 5 & $f$ & 1. & 2. & 0. & -0.02 & 0.992 & 0.008 & 0.000 \\
\hline- & $R^{* *}$ & 0.03 & 0.18 & 0.09 & -0.01 & 0.990 & 0.010 & 0.000 \\
\hline
\end{tabular}

* Standardized partial regression coefficient, average kernel yield was $83 \mathrm{~kg}$ dry weight are ${ }^{-1}$, see text.

** Maintenance and dark respirations of diseased leaf area. The estimate without disease stress is 0.03 proportion leaf weight respired per day at $25^{\circ} \mathrm{C}$.

did not deviate much and the average value of the parameters were best estimates, see methods. Results of the analyses are given in Table 3 . Years explained most of the variance of computed yields $\left(R^{2}\right.$-values about 0.9$)$. Therefore, the $R^{2}$-values given in Table 3 were computed after elimination of the effect of $u_{i}$.

Response in yield by the model to a change in the disease stress itself gave a $v_{\mathrm{m}}$-value of -0.06 , with this artificial epidemic. This estimate equals the $v_{\mathrm{m}}$-value of parameter $a$ from equation 1 (Table 3 ). This was to be expected as parameter $a$ also determines the disease stress. The gradient parameter $b$ of equation 2 , characterizing the mildew profile and parameter $c$ of equation 4 , determining the maximum reduction of $A_{\mathrm{m}}$ by mildew, had similar $v_{\mathrm{m}}$-values. These three appear to be the most important parameters. Parameter $d$ of equation 4, determining at which disease intensity the maximum reduction of $A_{\mathrm{m}}$ is reached, had a lower $v_{\mathrm{m}}$-value. The effect of parameter $f$ of equation 5 , determining the effect of mildew on the light use efficiency, was low. An increase of the maintenance and dark respirations $(R)$ by mildew gave a $\nu_{m}$-value close to zero, thus it affected computed yield hardly.

On average, yield response by the model to changes in parameter values was low. This implies that the disease has relatively little effect on computed yield. Response to changes in parameter values could be described satisfactorily by a linear relation (Table $\left.3, R^{2} v, x\right)$. Interactions with year $\left(R^{2} w_{\mathrm{i}}, x\right)$ and deviations from linearity (in $R^{2}$ error) were all relatively unimportant.

\section{Discussion}

Yield response of the model to changes in the value of parameter $f$ was low. As this parameter determines the amount of radiation intercepted by the mildewed leaf area $(f=1)$ this low $\nu_{\mathrm{m}}$-value compared to the others indicates that mildew affects the crop mainly by changes in the momentaneous radiation use efficiency and not by shading (Waggoner and Berger, 1987; Johnson, 1987). However, by a lower momentaneous radia- 
tion use efficiency, the rate of crop growth and leaf area growth is lowered, by which the consequent amount of radiation intercepted is lowered accordingly. Thus, damage by mildew cannot be attributed to the radiation use efficiency only, as this effect is confounded with the interception of radiation during the season. A consequence of this effect is that if crop growth is analysed in relation to the cumulative amount of radiation intercepted (Waggoner and Berger, 1987 and Lim and Gaunt, 1981), effects of diseases like mildew appear absent as small differences between the slopes of the relations are then hard to detect. To complete these analysis, the relation between the disease intensity and the total amount of radiation intercepted should be included.

Frame SUCROS87. Simulated damage due to powdery mildew approached measured, but on the average, the simulations underestimated measured damage. It was indicated that the underestimation in early epidemics was caused by the computation of the processes which determine the harvest index. However, if the computations would be made with a fixed harvest index, a systematic underestimation would be the result (Table 2). Therefore, also other processes leading to an underestimation are discussed. In the models, the assimilates produced on a day by mildewed leaves are added to those of healthy leaves. This bulk of assimilates is then partitioned and allocated to the different plant organs. However, it is questionable to what extent assimilates of mildewed leaves are transported to other organs in the plant (Heyland et al., 1979). For barley, Kern (1985) observed that the export of assimilates by mildewed leaves decreased, whereas the partitioning of assimilates was hardly affected. It is not clear from literature to what extent this reduced export is accounted for by the reduced assimilation assumed in this study. A mildew pustule may be thought of as a drain of carbohydrates (Edwards and Allen, 1966) and nitrogen, due to pustule growth and sporulation. Incorporation of this process (Van Roermund and Spitters, 1990) might improve the model. A related question is whether compensation by healthy top leaves when lower leaves are diseased (Walters and Ayres, 1983) should be taken into account. Hwang et al. (1986) did not found such a compensation.

The process of leaf dying was not considered. In the model, the relative death rate of leaves depends on temperature only. But, when assimilation decreases by mildew, the net growth rate of biomass and of leaf area decreases, accordingly. The death rate is confounded with growth, because the formation of new leaves is not explicit in the model. At flowering, assimilates are no longer allocated to leaves. A reduction in assimilation then does not lead to an increased death rate in the model, but in the field it does (Finney, 1979; Paulech and Haspelová-Horvatovicová, 1986). This is not a plea to model leaf death depending on mildew intensity, as no direct mechanism seems to operate (Walters and Wylie, 1986).

Light interception and photosynthesis were computed taking shading into account. Computed damage depended strongly on the steepness of the mildew profile. Lower leaves, being heavily diseased, had thus low photosynthetic capacities. This effect of mildew runs parallel with the effect of ageing (Rawson et al., 1983). Therefore, leaf death may be simulated in relation to ageing and shortage of carbohydrates in a leaf layer, caused by shading and by mildew.

Nitrogen. To simulate damage at different input levels of crop husbandry, the mildew intensity should be translated first into processes which govern the nitrogen dynamics.

Neth. J. Pl. Path. 96 (1990) 
Murray and Ayres (1986) report that in mildewed barley seedlings the nitrogen uptake rate per $\mathrm{mg}$ root was considerably reduced and that the loss of $\mathrm{N}$ from the leaves as a result of sporulation was comparatively small. The reduced uptake partly explains the reduction in $A_{\mathrm{m}}$ by mildew (Walters, 1985). When the epidemic proceeds, reduced growth of the plant reduces the $\mathrm{N}$ demand by the plant. Considering that a high level of fertilization enhances epidemics of mildew, the nitrogen dynamics in soil, plant and pathogen, appear to have many feedback mechanisms which should be considered if damage by mildew at different levels of crop husbandry is to be modelled.

Crop models and disease management. To bypass some of these problems, measurements in the field of biomass of the different organs of the crop can be made in spring to initialize the model. The processes leading to damage can then be studied accurately. The question remains whether the models will lead to general methods and have practical advantages in terms of labour requirement above traditional yield loss studies. If they do not have these advantages, the spin-off and other informal activities in relation to the objective of the work become important. The development of general methods to construct and apply damage functions under various weather conditions and crop husbandry practices is urgently needed. Though crop models provide a physiological frame for yield loss studies, they require more quantitative physiological knowledge. If the target is to actualize a disease management system, the effort should concentrate on field experiments, which give in addition to a damage function, more information on disease management.

\section{Acknowledgements}

We are grateful to professors R. Rabbinge and J.C. Zadoks and Dr C.J.T. Spitters for comments on the manuscript and to Mr G. van der Vliet for drawing the figures.

\section{Samenvatting}

Effecten van meeldauw en weersomstandigheden op opbrengsten van wintertarwe. 2. Effecten van meeldauwepidemieën

Opbrengstderving van wintertarwe werd berekend aan de hand van het effect dat meeldauw heeft op de blad-fotosynthese. Een rekenmodel voor de gewasgroei van tarwe werd uitgebreid met meeldauw. Met inachtneming van de vertikale en horizontale verdeling van meeldauw in het gewas, werd meeldauw in het model gekwantificeerd door vijf parameters. De belangrijkste parameters waren die van de meeldauwintensiteit, de verdeling van meeldauw in het gewas en het effect van meeldauw op de assimilatie bij een overvloed aan licht. Epidemieën van meeldauw, gemeten in veldproeven in drie verschillende jaren, werden gebruikt om opbrengstdervingen te berekenen. Gemiddeld kwam deze redelijk overeen met de in de veldproeven gemeten opbrengstderving. De gemeten opbrengstderving werd echter onderschat, vooral bij vroege epidemieën van meeldauw door de wijze waarop de (her)verdeling van assimilaten wordt berekend. Andere mechanismen, die een onderschatting van opbrengstderving kunnen veroorzaken worden besproken. Of deze modellen als methode gebruikt kunnen worden om systemen voor de geleide bestrijding van ziekten te verbeteren wordt bediscussieerd. 


\section{References}

Allen, P.J., 1942. Changes in the metabolism of wheat leaves induced by infection with powdery mildew. American Journal of Botany 29: 425-435.

Daamen, R.A., 1986. Measures of disease intensity in powdery mildew (Erysiphe graminis) of winter wheat. 1. Errors in estimating pustule number. Netherlands Journal of Plant Pathology 92: 197-206.

Daamen, R.A., 1988. Effects of nitrogen fertilization and cultivar on the damage relation of powdery mildew (Erysiphe graminis) in winter wheat. Netherlands Journal of Plant Pathology 94: 69-80.

Daamen, R.A., 1989. Assessment of the profile of powdery mildew and its damage function at low disease intensities in field experiments with winter wheat. Netherlands Journal of Plant Pathology 95: 85-105.

Daamen, R.A. \& Jorritsma, I.T.M., 1990. Effects of powdery mildew and wather on winter wheat yield. 1. Variation of weather between years. Netherlands Journal of Plant Pathology 96: 29-34.

Edwards, H.H. \& Allen, P.J., 1966. Distribution of the products of photosynthesis between powdery mildew and barley. Plant Physiology 41: 683-688.

Finney, M.E., 1979. The influence of infection by Erysiphe graminis on the senescence of the first leaf of barley. Physiological Plant Pathology 14: 31-36.

Heyland, K.U., Solansky, S. \& Becker, F.A., 1979. Die Assimilatspeicherung in der Sommerweizenahre unter dem Einfluss von Mehltaubefall (Erysiphe graminis) auf verschiedenen Assimilationsorganen. Zeitschrift fur Pflanzenkrankheiten und Pflanzenschutz 86: 513-532.

Hwang, B.K., Ibenthal, W.D. \& Heitefuss, R., 1986. ${ }^{14} \mathrm{CO}_{2}$-Assimilation and metabolism of ${ }^{14} \mathrm{C}$-assimilates in whole plants of spring barley in relation to adult-plant resistance to powdery mildew. Korean Journal of Plant Pathology 2: 22-30.

Johnson, K.B., 1987. Defoliation, disease, and growth: a reply. Phytopathology 77: 1495-1497.

Jorritsma, I.T.M., 1986. Effecten van meeldauw op de fotosynthese van wintertarwe. Doctoraal verslag. Landbouwuniversiteit Wageningen, $43 \mathrm{pp}$.

Kern, M., 1985. Phytohormongehalte und Assimilattransport in Sommergerstensorten mit unterschiedlicher Resistenz gegenuber dem echten Mehltau (Erysiphe graminis f.sp. hordel). Dissertation, Gottingen, $94 \mathrm{pp}$.

Lim, L.G. \& Gaunt, R.E., 1981. Leaf area as factor in disease assessment. Journal of Agricultural Science, Cambridge 97: 481-483.

Murray, A.J.S. \& Ayres, P.G., 1986. Uptake and translocation of nitrogen by mildewed barley seedlings. New Phytopathologist 104: 355-365.

Paulech, C. \& Haspelová-Horvatovicová, A., 1986. Influence of the parasitic fungus Erysiphe graminis upon the assimilative pigments of barley plants during the individual stages of pathogenesis. Photobiochemistry and Photobiophysics, 12: 177-180.

Rabbinge, R., Jorritsma, I.T.M. \& Schans, J., 1985. Damage components of powdery mildew in winter wheat. Netherlands Journal of Plant Pathology 91: 235-247.

Rawson, H.M., Hindmarsh, J.H., Fisher, R.A. \& Stockman, Y.M., 1983. Changes in leaf photosynthesis with plant ontogeny and relationships with yield per ear in wheat cultivars and 120 progeny. Australian Journal of Plant Physiology 10: 503-514.

Roermund, H.J.W. van \& Spitters, C.J.T., 1990. Simulation of yield reduction by leaf rust in winter wheat, applied to the analysis of genetic variation in partial resistance. Netherlands Journal of Plant Pathology 96: 17-28.

Schans, J., 1983. Schadecomponenten van meeldauw op tarwe. Doctoraal verslag. Landbouwuniversiteit Wageningen, $75 \mathrm{pp}$.

Spitters, C.J.T., Keulen, H. van \& Kraalingen, D.W.G., 1989. A simple and universal crop growth simulator: SUCROS87. In: Rabbinge, R., Ward, S.A. \& Laar, H.H. van (Eds), Simulation and systems management in crop protection. Simulation Monographs Pudoc, Wageningen, 147-181.

Neth. J. Pl. Path. 96 (1990) 
Taylor, L.R., Woiwod, I.P. \& Perry, J.N., 1979. The negative binomial as a dynamic ecological model for aggregation, and the density dependence of $k$. Journal of Animal Ecology 48: 289-304.

Ubels, E. \& Vliet, G. van der., 1979. Beoordeling van tarwe op aantasting door schimmelziekten. IPO Mededeling $\mathrm{Nr} 798,72 \mathrm{pp}$.

Vrede, H.C. van, 1983. Schaderelaties tussen meeldauw en tarwe. Doctoraal verslag. Landbouwuniversiteit Wageningen, $34 \mathrm{pp}$.

Waggoner, P.E. \& Berger, R.D., 1987. Defoliation, disease and growth. Phytopathology 77: 393-398.

Waggoner, P.E. \& Rich, S., 1981. Lesion distribution, multiple infection, and the logistic increase of plant disease. Proceedings of the National Academy of Science, USA 78: 3292-3295.

Walters, D.R., 1985. Shoot:root interrelationships: the effects of obligatory biotrophic fungal pathogens. Biological Review 60: 47-79.

Walters, D.R. \& Ayres, P.G., 1983. Changes in nitrogen utilization and enzyme activities associated with $\mathrm{CO}_{2}$ exchanges in healthy leaves of powdery mildew-infected barley. Physiological Plant Pathology 23: 447-459.

Walters, D.R. \& Ayres, P.G., 1984. Ribulose bisphosphate carboxylase protein and enzymes of $\mathrm{CO}_{2}$ assimilation in barley infected by powdery mildew (Erysiphe graminis f.sp. hordel). Journal of Phytopathology 109: 208-218.

Walters, D.R. \& Wylie, M.A., 1986. Polyamines in discrete regions of barley leaves infected with the powdery mildew fungus, Erysiphe graminis. Physiology of Plants 67: 630-633.

Zadoks, J.C., Chang, T.T. \& Konzak, C.F., 1974. A decimal code for the growth stages of cereals. Bulletin Eucarpia 7: 42-52. 